\title{
A Loophole In Financial Accounting: A Detailed Analysis Of Repo 105
}

Chun-Chia (Amy) Chang, Ph.D., San Francisco State University, USA

Joanne Duke, Ph.D., San Francisco State University, USA

Su-Jane Hsieh, Ph.D., San Francisco State University, USA

\begin{abstract}
From 2000 to 2008, Lehman used repo transactions to hide billions of dollars on their statements. They also misrepresented the repo transactions as "secured borrowings" even though they actually recorded the transactions as sales. Valukas' report in 2010 stimulated an extensive coverage of the repo transactions and spurred an array of studies addressing issues related to the collapse of financial institutions. Since the Repo 105 maneuver of Lehman provides a good example on how regulatory deficiencies can induce companies to obscure financial reporting and the importance of ethics in deterring these abuses, our study intends to examine repo transactions related accounting standards, illustrate how repo transactions can enhance a bank's financial statements, and discuss the importance of business ethics in curtailing accounting irregularities.
\end{abstract}

Keywords: Repo 105; creative accounting; business ethics

\section{INTRODUCTION}

¿ n March 2010, the Wall Street Journal (WSJ hereafter) published a series of reports regarding a practice called Repo 105 that was employed by the Lehman Brothers Holdings Inc. to obscure approximately $\$ 50$ billion of liabilities from investors. "A "Repo" is a "repurchase agreement" that enables short-term borrowers to gain liquidity. During a repo transaction, a company "sells" assets to others with a repurchase agreement signed simultaneously at the time of the sale. The repurchase at a higher price usually occurs immediately after the financial statements are issued, or a few days after the sale. This transaction is equivalent, in substance, to a secured borrowing with the underlying assets as collateral since the seller is obligated to buy back the assets. The difference between the selling price and the repurchase price is essentially the interest charged by the purchasing institution. The point of contention is whether repo transactions should be reported as a secured borrowing or as a sale. The choice of the reporting method will significantly impact the financial reporting.

Lehman reported repo transactions as "sales" of assets and failed to disclose its liabilities arising from the obligations to buy back the transferred assets. The repurchase price for transferred assets was set at $105 \%$ of the cash received from the sales. Therefore, Lehman (i.e., the transferor) claimed that it did not have sufficient cash to repurchase these assets back or replace them with similar assets. By reporting repos as sales of assets, Lehman was able to remove these toxic assets (e.g., subprime mortgage loans) from its books and use the cash received to reduce its liabilities. ${ }^{2}$ Lehman is not the only financial institution using repo transactions to enhance financial statements. This tactic was also used by other major U.S. banks (e.g., Bank of America, Citigroup, etc.) to improve their leverage ratios substantially immediately before the release of their quarterly statements. ${ }^{3}$

Valukas' report indicates that Lehman's SEC filings during the period of 2000 to third quarter, 2007, regularly misrepresented some repo transactions as "secured borrowings" despite the fact that it actually recorded the repo as "sales". Moreover, Lehman never disclosed its involvement in repo transactions in its 10-K report of 2007 and the first two 10-Q reports of 2008. The release of Valukas' report not only called the public's attention to repo practices, but also instigated an array of studies addressing the issues related to the collapse of Lehman and the repo transactions (Black, 2010). However, most of the reports and studies focus on the operations and the legal issues involved in conducting these repo transactions. None of these reports or studies addresses repo transactions 
from an accounting perspective except Herz's report to the House Financial Services Committee in April, 2010. Since the Repo 105 tactic used by Lehman and other major financial institutions provides an excellent example for the accounting profession to learn about the repercussions of regulatory deficiencies as well as the importance of business ethics in curtaining accounting irregularities, our paper focuses on examining repo transactions related accounting standards to contemplate the appropriate accounting, illustrating how the reporting of repo transactions as sales can enhance a bank's financial statements, and discussing the importance of business ethics in deterring accounting manipulations.

\section{INSIDE REPO 105: A LOOPHOLE IN ACCOUNTING STANDARDS}

\section{The Accounting Standards that helped Lehman obscure its risk exposure}

Statement of Financial Accounting Standards No. 140 (SFAS hereafter) provides guidelines on the reporting of financial asset transfers. For a transfer of financial assets to be accounted for as a sale, three conditions must be met: 1) the transferred assets need to be isolated from the transferor, 2) the transferee can pledge or exchange the assets, and 3) the transferor does not maintain effective control over the transferred assets through either a repurchase agreement or an ability to mandate the transferee to return the assets. A repo transaction can be accounted for as a sale only if all three of the above conditions are met. The structure of the repo contract can easily meet the first two required conditions. However, companies need to employ some accounting maneuvers to comply with the third criteria of not maintaining effective control.

Effective control is maintained only if the transferor has the ability to repurchase substantial amounts of the transferred assets. To demonstrate the ability to repurchase transferred assets, the transferor must maintain sufficient cash or other collateral to fund substantially all of the cost of purchasing the transferred assets at all times during the repurchase contract term. ${ }^{4}$ Thus, if a company can attest that cash holdings are insufficient for the repurchase of the transferred assets during the contract period, it would have exhibited a lack of ability to repurchase the assets, and therefore would not maintain effective control over the transferred assets. The firm has then met the third criteria of a sale by not maintaining effective control.

In the Repo 105, Lehman deliberately set the repurchase price to be $105 \%$ of the cash received. With this agreement of a higher repurchase price, Lehman claimed that it did not have adequate funds to repurchase the transferred assets. Consequently, the Repo 105 did not meet the conditions needed for maintaining effective control as stated in SFAS 140, paragraphs 47 and $49 .{ }^{5}$ Without effective control over the transferred assets, the third condition needed in reporting transferred assets as sales is also met. As such, Lehman accounted for the Repo105 transactions as sales instead of secured borrowings.

One might wonder how the FASB defines the amount to be sufficient enough to substantially fund all of the cost of repurchasing the transferred assets and why setting the repurchase price at $105 \%$ of the cash received in the Lehman's Repo contract is considered insufficient funds to either fulfill the repurchase obligation or to replace the transferred assets. The answer is found in SFAS 140, paragraph $218 .^{6}$ This paragraph states that the transferor's repurchase right is only assured when the repurchase price is $102 \%$ or less of the cash received, or the cash received is $98 \%$ or more of the value of the collateralized assets (i.e., the repurchase price). By deliberately setting the repurchase price above the $102 \%$ (e.g., at 105\%) of the cash received, Lehman argued that it did not possess sufficient cash for the repurchase according to the criteria stated in SFAS 140. Without the assurance for repurchase, the company did not meet the key criteria of maintaining effective control over the transferred assets and therefore reported its Repo 105 as a sale.

Based on the above analysis, Lehman's treatment of the Repo 105 may not be entirely improper from an accounting perspective. Lehman seemed to account for those transactions as required by the Generally Accepted Accounting Principles even though it had to structure the repo transaction to circumvent some standards. 
The FASB's Attempt to Improve Transparency and the Reporting Quality of Repo Transactions: Release of Statement of Financial Accounting Standards No.166 and the Exposure Draft for Repurchase Agreements

In June 2009, the FASB issued SFAS 166 (to amend SFAS 140) and SFAS 167 (to amend FASB Interpretation No. 46(R)) pertaining to securitizations and special purpose entities. These standards have begun to impact companies' balance sheets in 2010 with delayed implementation for financial institutions. SFAS 166 not only attempts to improve the reporting of transferred financial assets, but also completely eliminates the reporting approach for the qualifying special-purpose entity. SFAS 166 also extends the examples of "effective control" provided in SFAS140. According to SFAS 166, when a transfer of financial assets includes an agreement to grant the transferee the right to require the transferor to repurchase the transferred assets at a favorable price (with the price so favorable that the transferee is likely to exercise its right); this constitutes an example of the transferor's upholding effective control over the assets. In the case where the repo transaction is substantially over-collateralized (e.g., Repo 105 transactions), it is likely that the transferee would demand the repurchase. As a result, had the Repo 105 of Lehman included such an agreement, Lehman's claim based on SFAS 140 of not maintaining effective control over the transferred assets would be invalid under SFAS 166. Lehman would therefore have had to account for the Repo 105 as secured borrowings. On the other hand, when a Repo contract does not contain the above agreement, Lehman's argument used in reporting its Repo 105 as sales would still be justifiable even under SFAS 166.

The FASB states that the objective of SFAS 166 is to improve the reporting of transferred financial assets, particularly the effects of the transfer on the reports and the transferor's continuing involvement in the transferred assets. Based on our analysis, we conclude that even though SFAS 166 overcomes some regulatory deficiencies in reporting transferred financial assets, it does not eliminate the loopholes in reporting repo transactions as sales. Following SFAS 166, companies are still able to structure repo transactions similar to Lehman's Repo 105 and use the same argument Lehman used in reporting repos as sales. To treat a repo 105 transaction as a sale, companies would only need to write the repo contract excluding the agreement of permitting the transferee to require the repurchase.

As pointed out in the preceding discussion, the current standard (i.e., ASC 860-10-40-24 (b) or SFAS 140, paragraph 49) requires the transferor to possess sufficient funds for the repurchase during the repo contract period in order to claim effective control over the transferred assets. This requirement had induced discretionary interpretations and led to accounting manipulations to report repo transactions as sales. Moreover, despite some improvements on the reporting of transferred financial assets, SFAS 166 cannot effectively close the loopholes of repo accounting. For example, it would not prevent the case of Lehman's Repo 105 transaction recorded as a sale in the case where the contract excludes the agreement to grant the transferee the right to require the transferor to repurchase the transferred assets at a favorable price. Consequently, in a continuing effort to eradicate the loopholes in repo reporting, the FASB issued the Exposure Draft: Transfer of Receivables and Services - Repurchase Agreement, in November 2010. This Exposure Draft proposes, in contrast to the current accounting standards (i.e., SFAS 140 and SFAS 166), using the repurchase contractual obligation as the criterion to determine whether effective control exists over transferred assets. If this proposal passes, it will significantly affect the reporting of repo transactions. Companies have to report repos as secured borrowings as long as there is a repurchase agreement. This proposal is a step closer to the convergence to the derecognition rules of the IASB (i.e., IAS 39) in which the transferor's ability to repurchase is not a consideration in assessing control of the transferred assets.

\section{THE IMPACT OF REPO 105 ON FINANCIAL REPORTING}

\section{Ambiguities Abound: Is it a Sale or a Borrowing?}

The Impact on Financial Statements:

The repurchase transaction can be a sale or a financing based on the standards described above. We use a hypothetical example to illustrate the financial statement effects of the "off-balance sheet" treatment, specifically recording the repurchase as a sale. Consider the following example: 
On December 31, 2010, San Francisco Bank signed a repo agreement with IAA Bank, and received \$1 million cash. According to the repo agreement, San Francisco Bank transfers its mortgage receivable, with a book value of $\$ 1.05$ million, to IAA and agrees to buy back these transferred assets at $\$ 1.05$ million. The following table shows amounts prior to this repo agreement, and after the repo agreements under two different accounting treatments:

Table 1

\begin{tabular}{|c|c|c|c|}
\hline Selected financial data & $\begin{array}{c}\text { Amounts } \\
\text { prior } \\
\text { to Repo agreement }\end{array}$ & $\begin{array}{l}\text { Amounts } \\
\text { under } \\
\text { a sale } \\
\end{array}$ & $\begin{array}{c}\text { Amounts } \\
\text { under a } \\
\text { borrowing }\end{array}$ \\
\hline \multicolumn{4}{|l|}{ Assets: } \\
\hline Cash & $\$ 1,000,000$ & $\$ 2,000,000$ & $\$ 2,000,000$ \\
\hline Mortgages receivable & $2,200,000$ & $1,150,000$ & $2,200,000$ \\
\hline All other assets & $1,800,000$ & $1,800,000$ & $1,800,000$ \\
\hline Total Assets & $\$ 5,000,000$ & $\$ 4,950,000$ & $\$ 6,000,000$ \\
\hline \multicolumn{4}{|l|}{ Liabilities and equity: } \\
\hline Liabilities & $3,700,000$ & $3,700,000$ & $4,700,000$ \\
\hline Equity & $1,300,000$ & $1,250,000$ & $1,300,000$ \\
\hline Total Liabilities and equity & $\$ 5,000,000$ & $\$ 4,950,000$ & $\$ 6,000,000$ \\
\hline $\begin{array}{l}\text { After tax income for the year ended } \\
\text { December } 31,2010\end{array}$ & $\$ 550,000$ & $\$ 500,000$ & $\$ 550,000$ \\
\hline
\end{tabular}

When the repo transaction is treated as a sale, the balance of cash increases by $\$ 1$ million and the balance of mortgages receivable declines by $\$ 1.05$ million. The difference of $\$ 50,000$ is recorded as a forward purchase commitment, resulting in a reduction in equity. When the repo is reported as a secured borrowing, the balance of cash increases by $\$ 1$ million, the mortgage receivable balance remains unchanged and the liabilities balance will increase by 1 million. The following table shows the impact on two key financial ratios under two different accounting treatments for the repo transaction:

Table 2

\begin{tabular}{lcc}
\hline & $\begin{array}{c}\text { Ratios under } \\
\text { sale accounting scenario }\end{array}$ & $\begin{array}{c}\text { Ratios under } \\
\text { borrowing scenario }\end{array}$ \\
\hline Return-on-assets ratio & $\$ 500,000 / \$ 4,950,000=0.10$ & $\$ 550,000 / \$ 6,000,000=0.09$ \\
Debt-to-equity ratio & $\$ 3,700,000 / \$ 1,250,000=2.96$ & $\$ 4,700,000 / \$ 1,300,000=3.62$ \\
\hline
\end{tabular}

This example indicates that reporting the repo transaction as a sale results in an $11 \%$ higher return-onassets ratio than the secured borrowing reporting. On the other hand, the reporting of the repo transaction as a sale results in an $18 \%$ reduction in the leverage ratio. As demonstrated in this example, by reporting repo transactions as sales instead of secured borrowings, a firm can enhance the profitability ratio and depict a less risky financial position.

\section{THE KEY TO PREVENTING UNETHICAL CORPORATE PRACTICES}

Lehman was not alone in reporting repo transactions as sales. Bank of America and Citigroup were both found to misclassify repo transactions as sales in the last three years with the amount ranging from $\$ 573$ million to $\$ 10.7$ billion for Bank of America and from \$5.7 billion to \$9.2 billion for Citigroup. The reporting of Repo 105 transactions as sales may appear to be technically in compliance with U. S. GAAP in which all U.S. public firms are required to adhere, however, based on the full disclosure principle of the conceptual framework, the obligations to buy back assets should, at least, be disclosed. ${ }^{7}$ This disclosure of obligations is also in compliance with representational faithfulness, an important fundamental qualitative characteristic according to Statement of Financial Accounting Concepts No. 8. Moreover, from a legal standpoint, Lehman's obligation to buy back transferred assets 
should warrant a mandate for the firm to disclose the obligation. As matter of fact, Lehman could not find a U.S. law firm willing to give an opinion that its Repo 105 transaction was a sale. Lehman had to obtain the sale opinion from Linklaters, a London-based law firm, and conduct all its repo transactions through its European branches to borrow mainly from non-U.S. banks such as U.K.'s Barclays PLC (Craig \& Spector, 2010). As such, it is unethical for Lehman to report the repos as sales while it had the obligation to buy back the transferred assets overnight or in a few days.

It seems that accounting manipulation is inevitable with rules-based standards that exist in U.S. GAAP. However, there has been an emphasis on accountants to look at the economic substance of a transaction rather than just rely on form (such as the $102 \%$ rule). The Accounting Principles Board (APB), the predecessor of the FASB, declared in Statement No. 4 that "Accountants emphasize the substance of events rather than their form so that the information provided better reflects the economic activities represented". Further, the present accounting authorities, the FASB and the SEC, continue to stress the "substance" of transactions. However, this concept of "substance" seems to be lacking in the Repo transactions of Lehman and others. The result is the perception of ethical violations. The accounting maneuver of Lehman's Repo 105 provides concrete evidence that high ethical standards within the accounting profession are a necessary condition to preserve the proper implementation of accounting standards.

Since adhering to the highest standards of ethical conduct promotes investors' confidence in the firms' financial reporting, the importance of business ethics has been emphasized in all aspects of the accounting profession. For example, the primary tenets of the AICPA Code of Professional Conduct for auditors (www.AICPA.org) states that integrity is an accountant's obligation to be honest in reports. This implies that full disclosure and the substance of transactions should be critical to auditors in order to maintain the public's confidence in financial statements. Further, the Institute of Management Accountants requires the firms' internal accountants to act in accordance with their specified set of ethical principles. The code also encourages others in the firm, that is the non-accountants, to adhere to these ethical guidelines. In the academic environment, we have been promoting the importance of ethics in education. Business schools should require an ethics course as part of the curriculum or at the least include ethics within various classes. In fact, the new 150-hour education requirement proposed by the California Board of Accountancy is considering requiring ten units of ethics classes in order to receive CPA certification. If the professional codes of conduct for accountants and auditors can be abided, many of these unethical practices may be effectively eliminated.

\section{CONCLUSION}

Even though the deficiencies in standards relating to the consolidations of special purpose entities (with billions of subprime mortgage loans used as collateral in issuing commercial papers) is considered to be one of the main causes of the recent financial market crisis, the debacle of Lehman in September 2008 triggered the crisis. Many factors contributed to the collapse of Lehman. The most notable one is perhaps the Repo 105 maneuver used by the company to conceal billions of dollars of liabilities from investors, the auditor and the SEC. Not only had Lehman employed this repo technique since 2000, but it has also been a popular practice among other U.S. Banks and financial institutions. It is a bit disheartening that it was never brought to the attention of the regulatory and standard setting authorities until pointed out by Valukas, a bankruptcy court appointed Examiner of Lehman, in 2010. Mr. Valukas devoted more than 300 pages of its report in describing how Lehman used Repo 105 to remove billions of illiquid assets and liabilities from its balance sheet without even disclosing its obligations to repurchase these assets.

Two issues are immediately apparent. Why did it take the regulatory bodies so long to respond to the corruption and why didn't the accountants and auditors involved place more emphasis on the ethical codes of conduct required of its members? The public's confidence in financial reporting will be eroded by the accounting profession's lack of response to accounting irregularities and scandals. FASB has made a move to close the reporeporting loophole (i.e., the Exposure Draft on repurchase agreement, 2010). It has proposed to assess effective control of transferred assets based solely on the contractual obligation rather than relying on the repurchase ability. If this proposal passes, FASB would have effectively put an end to the loophole of repo reporting. However, this response is occurring almost ten years after the Repo 105 was put into practice. 


\section{AUTHOR INFORMATION}

Chun-Chia (Amy) Chang is an assistant professor at San Francisco State University. Her research interest is in financial reporting with specific emphasis on issues relating to quality of financial reports, earnings management, earnings quality, and corporate governance. E-mail: amychang@ @fsu.edu

Joanne Duke is professor at San Francisco State University. Her research interests include financial reporting issues. She has published papers in the Journal of Accounting and Economics, the Journal of Business Finance and Accounting, Risk management, and the Journal of Business Management, among others. E-mail: jduke@sfsu.edu

Su-Jane Hsieh is a professor at San Francisco State University. Her research interest is in financial reporting. She has published papers in various journals including Contemporary Accounting Research, Journal of Financial and Quantitative Analysis, Advances in Accounting, Journal of Accounting, Auditing and Finance, and Journal of Business, Finance and Accounting, among others. E-mail: sjhsieh@sfsu.edu

\section{NOTES}

1. The following are representative articles published in 2010 of the Wall Street Journal addressing Repo 105: Johnson, F. (2010). SEC concedes Lehman shortcomings - Schapiro tells House panel that oversight was 'inadequately staffed', surprise of Repo 105. The Wall Street Journal, March 18, 2010.

Reilly, D. (2010). The Lehman bankruptcy report: Questions on Ernst auditing - Examiner's report on Lehman's collapse focuses on role of accounting firm. The Wall Street Journal, March 15, 2010. Spector, M., Craig, S. \& Lattman, P. (2010). Examiner: Lehman torpedoed Lehman. The Wall Street Journal, March 12, 2010.

2. According to Black (2010), Lehman has securitized more than $\$ 100$ billion of its loans in 2007 through its subsidiaries, Aurora, BNC Mortgage LLC and Finance America.

3. The following are a series of articles that appeared in the Wall Street Journal addressing the repo maneuver used by some major U.S. banks:

Rapoport, M. (2010). BofA, Citi "Repos" hid debt - disclosures cite accidental misclassification of borrowings; no material impact. The Wall Street Journal, May 27, 2010. (2010). BofA admits hiding debt - details come as SEC is set to unveil review of Wall Street 'window dressing'. The Wall Street Journal, July 10, 2010. (2010). SEC had 'window dressing' on radar for years - since 2004, agency has questioned 102 companies; booking trades as sales instead of borrowings. The Wall Street Journal, July 21, 2010. (2010). Regulators to target 'window dressing'. The Wall Street Journal, September 16, 2010.

4. The repurchase conditions are stated in the SFAS 140, paragraph 47 or now codified as ASC 860-10-40-24 (a, $\mathrm{c}$ and d). In addition to the repurchase ability condition, three other conditions for maintaining effective control of transferred assets are: 1) the repurchased assets are the same or substantially the same as those of the transferred assets, 2) the repurchase is to occur before the maturity of the underlying assets at a fixed price, and 3) the repurchase agreement is signed at the time of transfer of assets.

5. SFAS 140, paragraph 47 and 49 is also codified as ASC 860-10-40-24 (b).

6. SFAS 140, paragraph 218 is also codified as ASC 860-10-55-37.

7. Freifeld, K. \& Sandler, L. (2010). Ernst \& Young said to face fraud lawsuit from Cuomo over Lehman audits. Bloomberg. 12/20/2010. The article reported that Ernst \& Young, the auditor of Lehman, will be sued by the New York Attorney General for helping Lehman mislead investors on Lehman's Repo transactions related liabilities.

\section{REFERENCES}

1. American Institute of Public Accountants. Basic concepts and accounting principles underlying financial statements of business enterprises (Statement No.4), 1970.

2. American Institute of Public Accountants. AICPA Code of Professional Conduct, www.AICPA.org.

3. Black, W. (2010). A statement to the House Financial Services Committee: Public policy issues raised by the report of the Lehman bankruptcy examiner. April 20, 2010. 
4. Craig, S. \& Spector, M. (2010). Repos played a key in Lehman's demise - report exposes lack of information and confusing pacts with lenders. The Wall Street Journal, March 13, 2010.

5. Financial Accounting Standards Board. Statement of Financial Accounting Standards No. 140: Accounting for transfers and servicing of financial assets and extinguishments of liabilities (now codified as ASC 86010-40).

6. Financial Accounting Standards Board, Statement of Financial Accounting Standard No. 166: Accounting for transfers of financial assets - an amendment of FASB Statement No. 140.

7. Financial Accounting Standards Board, Statement of Financial Accounting Standard No. 167: Amendments to FASB Interpretation No. 46 (R).

8. Financial Accounting Standards Board Interpretation No. 46 (R): Consolidation of variable interest entities - an interpretation of ARB No. 51.

9. Financial Accounting Standards Board, Exposure Draft: Transfers and servicing (Topic 860), November 3, 2010.

10. Financial Accounting Standards Board, Statement of Financial Accounting Concepts No. 8: Conceptual framework for financial reporting - Chapter 1: The objective of general purpose financial reporting, and chapter 3: Qualitative characteristics of useful financial information.

11. Herz, R. (2010). A report to the House Financial Services Committee: Discussion of selected accounting guidance relevant to Lehman accounting practices, April 19, 2010.

12. Johnson, F. (2010). SEC concedes Lehman shortcomings - Schapiro tells House panel that oversight was 'inadequately staffed', surprise of Repo 105. The Wall Street Journal, March 18, 2010.

13. Rapoport, M. (2010). BofA, Citi "Repos" hid debt - disclosures cite accidental misclassification of borrowings; no material impact. The Wall Street Journal, May 27, 2010.

14. _ (2010). BofA admits hiding debt - details come as SEC is set to unveil review of Wall Street 'window dressing'. The Wall Street Journal, July 10, 2010.

15. (2010). SEC had 'window dressing' on radar for years - since 2004, agency has questioned 102 companies; booking trades as sales instead of borrowings. The Wall Street Journal, July 21, 2010.

16. (2010). Regulators to target 'window dressing'. The Wall Street Journal, September 16, 2010.

17. Reilly, D. (2010). The Lehman bankruptcy report: Questions on Ernst auditing - Examiner's report on Lehman's collapse focuses on role of accounting firm. The Wall Street Journal, March 15, 2010.

18. Spector, M., Craig, S. \& Lattman, P. (2010). Examiner: Lehman torpedoed Lehman. The Wall Street Journal, March 12, 2010.

19. Valukas, A. (2010). Lehman Brothers Holding Inc. Chapter 11 proceedings examiner's report. United States Bankruptcy Court southern district of New York, March 11, 2010. 


\section{NOTES}

